Daly, J. R., Loveridge, N., Bitensky, L., and Chayen, J. (1974 b). Clinical Endocrinology. In press.

Daly, J. R., Myles, A. B., Bacon, P. A., Beardwell, C. G., and Savage, 0. (1967). Annals of the Rheumatic Diseases, 26, 18

Greenwood, F. C., Landon, J., and Stamp, T. C. B. (1966). Fournal of Clinical Investigation, 27, 183.

Jacobs, H. S., and Nabarro, J. D. N. (1969). Quarterly fournal of Medicine, $38,475$.

Jasani, M. K., et al. (1967). Quarterly Fournal of Medicine, 36, 267.
Landon, J., Wynn, V., and James, V. H. T. (1963). Fournal of Endocrinology, $27,183$.

Livanou, T., Ferriman, D., and James, V. H.T. (1967). Lancet, 2, 856.

Myles, A. B., Bacon, P. A., and Daly, J. R., (1971). Annals of the Rheumatic Diseases, 30, 149.

Plumpton, F. S., Besser, G. M., and Cole, P. V. (1969). Anaesthesia, 24, 3.

Spencer-Peet, J., Daly, J. R., and Smith, V. (1965). Fournal of Endocrinology, 31, 235.

\title{
Alpha-Fetoprotein Levels in Amniotic Fluids from Spontaneous Abortions
}

\author{
MARY J. SELLER, M. R. CREASY, EVA D. ALBERMAN
}

British Medical fournal, 1974, 2, 524-525

\section{Summary}

Alpha-fetoprotein (A.F.P.) levels in the amniotic fluid were determined in 54 cases of spontaneous abortion in which the amniotic sac remained intact. These levels were correlated with the morphological and cytogenetic status of the fetus. Of the 29 fetuses with no apparent abnormality 22 had A.F.P. levels below $50 \mu \mathrm{g} / \mathrm{ml}$, while 10 of the 11 fetuses with severe neural tube defects had raised levels $(50-305 \mu \mathrm{g} / \mathrm{ml})$. Seventeen fetuses had chromosome anomalies of various types. Three out of four which were $45, X$ had considerably raised A.F.P. levels $(78-210 \mu \mathrm{g} / \mathrm{ml}$ ) but fetuses with other chromosome constitutions and no neural tube defects had levels no higher than $32 \mu \mathrm{g} / \mathrm{ml}$.

\section{Introduction}

The observation by Brock and Sutcliffe (1972) that there is a connexion between a raised alpha-fetoprotein (A.F.P.) level in the amniotic fluid and severe neural tube defects in the fetus evoked great interest. A number of clinical investigations were instigated, and now amniotic fluid A.F.P. estimations are proving invaluable in the early prenatal diagnosis of fetuses with severe neural tube defects (Seller et al., 1974).

A.F.P. first appears in the amniotic fluid around six weeks of gestation and the levels rise to attain a maximum value between 13 and 15 weeks of gestation (Gitlin and Boesman, 1966). While it is well documented that in the case of fetuses with neural tube defects the A.F.P. level is considerably raised above normal from the 14th week of gestation, because amniocentesis is possible from this time, our knowledge of the situation in the first trimester is very limited (Allan et al., 1973).

This led us to examine the A.F.P. content of the amniotic fluids derived from spontaneous abortions where the aborted material consisted of a fetus inside an intact chorion and amniotic sac. In addition to obtaining data on the levels of A.F.P. in fetuses with neural tube defects we were also interested to discover whether there is any alteration in the amniotic fluid A.F.P. level when there is a chromosome aberration in the fetus. Chromosome anomalies are common in fetuses from spontaneous abortions. More than one estimate has put the overall

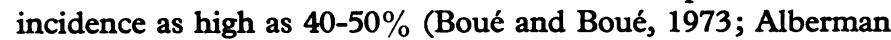
and Creasy, 1974). \footnotetext{
Paediatric Research Unit, Guy's Hospital Medical School, London
SE1 9RT

MARY J. SELLER, B.SC., PH.D., Lecturer

M. R. CREASY, M.SC., Research Assistant

EVA D. ALBERMAN, M.D., D.P.H., Senior Lecturer
}

Our findings show that amniotic fluid A.F.P. levels are raised in fetuses with neural tube defects which have been spontaneously aborted from the seventh week of gestation onwards and that they are also raised in fetuses with a $45, X$ chromosome constitution, but the levels in fetuses with other chromosome anomalies are normal.

\section{Methods}

The products of spontaneous abortions were collected daily from several hospitals in and around London as part of a survey currently being carried out in the paediatric research unit.

Amniotic fluid was aspirated into a hypodermic syringe from specimens which consisted of an intact chorion and amniotic sac. The fluid was subsequently discarded if it was blood stained or if the sac when opened did not contain a morphologically recognizable fetus.

The crown-rump length of the fetus was measured, and the fetus was examined under a binocular microscope for any gross morphological abnormality. The age of the fetus was calculated from the date of the first day of the last menstrual period of the mother. A small portion of gonad or extraembryonic membrane was set up in tissue culture, and after about three-weeks growth mitotic chromosome preparations were made by conventional methods. Apart from the usual orcein stain, trypsin banding and fluorescent techniques were also used. The chromosomes were analysed separately by two people.

Cellular debris was removed from the amniotic fluid by centrifugation at 2,000 r.p.m. for five minutes. The supernatant was stored in the deep freeze for several days to several weeks before A.F.P. estimation. The A.F.P. was assayed by onedimensional antigen/antibody-crossed electrophoresis as previously described (Seller et al., 1973). Quantitative estimations were made by reference to a standard provided by $\mathrm{Dr}$. $\mathrm{M}$. Adinolfi. Morphologic and cytogenetic details of the fetuses were withheld from the person performing the A.F.P. assay until after the levels had been determined.

\section{Results}

A total of 54 amniotic fluids were assayed for A.F.P. derived from sacs spontaneously aborted from the seventh to the 27th week of gestation. The associated fetuses were almost always macerated and very small in size for gestational age. Despite this, tissue culture was successfully achieved and chromosome analysis was possible in 48 cases (89\%). The A.F.P. levels from specimens in which no chromosome results were obtained have been included in the results.

The A.F.P. levels obtained from the amniotic fluids of fetuses with no morphological or chromosomal abnormality and from those with severe neural tube defects are shown in the chart. Out of 29 ostensibly normal fetuses 22 had A.F.P. levels below $50 \mu \mathrm{g} / \mathrm{ml}$ (range $<1-49 \mu \mathrm{g} / \mathrm{ml}$ ), and the remaining seven fell between 50 and $565 \mu \mathrm{g} / \mathrm{ml}$. By contrast all eight fetuses with 
- Neural tube defect
Control

$\circ$

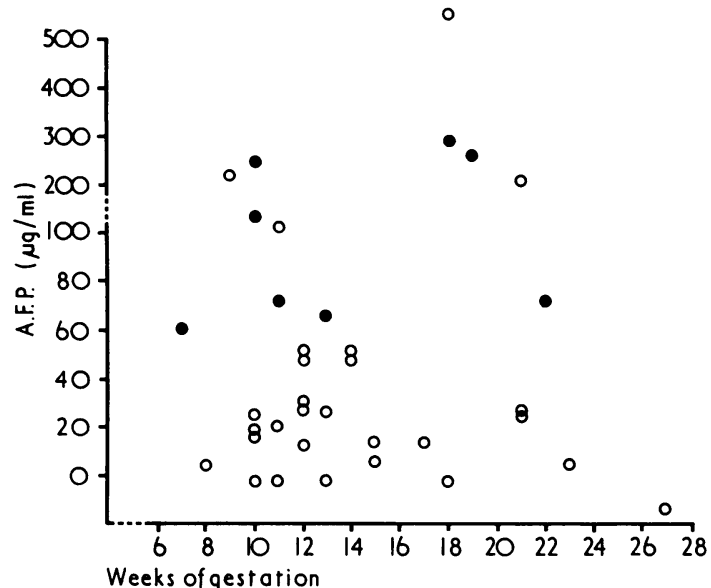

A.F.P. levels in amniotic fluids from spontaneous abortions where fetuses had no obvious morphological or chromosomal abnormality (controls) and in those where fetuses had some neural tube defects.

A.F.P. Levels in Fetuses from Spontaneous Abortions with Neural Tube Defects and no Chromosome Anomaly, with Chromosome Anomaly and no Neural Tube Defects, and with both Neural Tube Defects and Chromosome Anomaly

\begin{tabular}{|c|c|c|c|c|}
\hline $\begin{array}{l}\text { Fetus } \\
\text { No. }\end{array}$ & $\begin{array}{c}\text { Gesta- } \\
\text { tional } \\
\text { Age } \\
\text { (Weeks) }\end{array}$ & Abnormality & $\begin{array}{c}\text { A.F.P. } \\
\text { Level } \\
(\mu \mathrm{g} / \mathrm{ml})\end{array}$ & Chromosome Constitution \\
\hline \multicolumn{5}{|c|}{ Fetuses with Neural Tube Defects and no Chromosome Anomaly } \\
\hline $\begin{array}{l}1 \\
2 \\
3\end{array}$ & $\begin{array}{r}7 \\
10 \\
10\end{array}$ & $\begin{array}{l}\text { Thoracic spina bifida } \\
\text { Frontal encephalocoele } \\
\text { Cyclops with parietal } \\
\text { encephalocoele }\end{array}$ & $\begin{array}{r}64 \\
150 \\
265\end{array}$ & $\begin{array}{l}\text { No growth } \\
\text { 46, XX } \\
\text { No growth }\end{array}$ \\
\hline $\begin{array}{l}4 \\
5\end{array}$ & $\begin{array}{l}11 \\
13\end{array}$ & $\begin{array}{l}\text { Spina bifida } \\
\text { Occipital } \\
\text { encephalocoele }\end{array}$ & $\begin{array}{l}76 \\
70\end{array}$ & $\begin{array}{l}\text { No growth } \\
46, \mathrm{XY}\end{array}$ \\
\hline $\begin{array}{l}6 \\
7 \\
8\end{array}$ & $\begin{array}{l}13 \\
19 \\
22\end{array}$ & $\begin{array}{l}\text { Exencephaly } \\
\text { Anencephaly } \\
\text { Exencephaly }\end{array}$ & $\begin{array}{r}305 \\
280 \\
76\end{array}$ & $\begin{array}{l}46, X Y \\
46, X Y \\
46, X X\end{array}$ \\
\hline \multicolumn{5}{|c|}{ Fetuses with Chromosome Anomaly and no Neural Tube Defects } \\
\hline $\begin{array}{r}9 \\
10 \\
11 \\
12 \\
13 \\
14 \\
15 \\
16 \\
17 \\
18 \\
19 \\
20 \\
21 \\
22\end{array}$ & $\begin{array}{l}13 \\
10 \\
10 \\
12 \\
13 \\
15 \\
15 \\
10 \\
11 \\
12 \\
13 \\
9 \\
10 \\
13\end{array}$ & & $\begin{array}{r}<1 \\
5 \\
<1 \\
<1 \\
<1 \\
<1 \\
32 \\
21 \\
9 \\
21 \\
14 \\
210 \\
175 \\
78\end{array}$ & 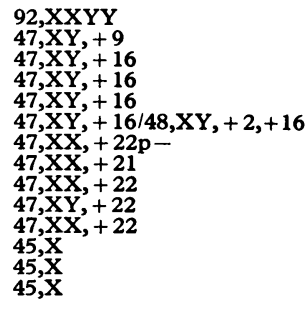 \\
\hline \multicolumn{5}{|c|}{ Fetuses with both Neural Tube Defects and Chromosome Anomuly } \\
\hline 23 & 11 & $\begin{array}{l}\text { Occipital } \\
\text { encephalocoele }\end{array}$ & 50 & $47, \mathrm{XX},+\mathrm{D}$ \\
\hline 24 & 19 & $\begin{array}{l}\text { Frontal } \\
\text { encephalocoele }\end{array}$ & 20 & $45, X$ \\
\hline 25 & 16 & Lumbar spina bifida & 115 & $69, \mathrm{XXY}$ \\
\hline
\end{tabular}

neural tube defects (but without chromosome anomalies) had amniotic fluid A.F.P. levels greater than $50 \mu \mathrm{g} / \mathrm{ml}$ (range 64-305 $\mu \mathrm{g} / \mathrm{ml}$ ). Details of the neural tube defects of these eight cases are given in the table.

Fourteen fetuses had a chromosomal anomaly and no apparent neural tube defect (see table). These included a tetraploid, trisomies in the $\mathrm{C}, \mathrm{E}$, and $\mathrm{G}$ groups, and three cases with $\mathrm{X}$ chromosome monosomy. Eleven of the cases, which included a variety of chromosome aberrations, ranged between $<1 \mu \mathrm{g} / \mathrm{ml}$ and $32 \mu \mathrm{g} / \mathrm{ml}$. But the three cases with a $45, \mathrm{X}$ chromosome constitution had considerably raised levels $(78 \mu \mathrm{g}, 175 \mu \mathrm{g}$, and $210 \mu \mathrm{g} / \mathrm{ml}$ ).

Three fetuses had both chromosome anomalies and neural tube defects (see table). One had a frontal encephalocoele, $\mathrm{X}$ chromosome monosomy, and an A.F.P. level of only $20 \mu \mathrm{g} / \mathrm{ml}$. A D trisomic with an occipital encephalocoele had a level of $50 \mu \mathrm{g} / \mathrm{ml}$, and a triploid with a lumbar spina bifida had a level of $115 \mu \mathrm{g} / \mathrm{ml}$.

\section{Discussion}

Our most notable finding, and one not reported before, was that the amniotic fluid A.F.P. level was raised in three of four fetuses with a 45, X chromosome constitution. Other fetuses examined, however, which between them had a variety of other chromosome anomalies, did not have raised A.F.P. levels. Secondly, we found that all aborted fetuses which had severe neural tube defects, except the one which was $45, \mathrm{X}$ as well, had considerably raised A.F.P. levels in the liquor. This is in accord with observations on fluids from fetuses with these abnormalities obtained by amniocentesis. In addition our study included six fetuses from the 7th to 13th week of pregnancy, which extended our knowledge on amniotic fluid A.F.P. levels in neural tube defects into the first trimester.

It has been suggested that the raised amniotic fluid levels in fetuses with neural tube defects is due to enhanced exudation of fetal elements through the exposed neural tissue or choroid plexus (Brock and Sutcliffe, 1972). Accordingly it is tempting to speculate why the $\mathrm{X}$ monosomics, alone among the chromosome aberrations, should have a raised A.F.P. in their liquor. A feature exclusive to the fetal XO phenotype is the fluid-filled pouches of skin in the cervical region. This does not occur in every case of $\mathrm{X}$ chromosome monosomy, but it is relatively common. It is particularly conspicuous in fetuses older than those with which we were dealing at present, but one fetus (fetus 20) did show considerable cervical oedema. Possibly these pouches represent a permeable site through which fetal components, including A.F.P., may leak into the liquor.

One fetus studied had both $\mathrm{X}$ chromosome monosomy and a frontal encephalocoele but no raised A.F.P. level. This fetus was severely macerated, however, and despite a gestational age of 19 weeks had a crown-rump length of only $17 \mathrm{~mm}$. Presumably this fetus had been dead in utero for some time, so fetal liver production of A.F.P. would have stopped long before, and the yolk sac-the other main site of A.F.P. synthesis in the fetus (Gitlin and Boesman, 1967)-would certainly be atretic by the 19th week of gestation. Thus the A.F.P. which was detected probably represented a residual trace of a very much higher level present when the fetus was alive. The half life of A.F.P. is known to be very short in neonates (around five days), when synthesis has essentially stopped (Gitlin and Boesman, 1966). The other two fetuses with both chromosomal and neural tube defects had raised A.F.P. levels. We assume this was due to abnormalities in their central nervous systems.

Seven fetuses with no obvious abnormality had raised A.F.P. levels, four of which were exceptionally high. We have no explanation for this finding, but it is possible that these fetuses had an abnormality or constellation of defects not overtly detectable which may also be associated with a high amniotic fluid A.F.P. level.

We thank Miss M. Elliott for obtaining the clinical data, Mr. J. A. Crolla, Mrs. A. R. Grant, and Miss R. Brown for skilled technical help. Mr. J. A. Crolla kindly provided the chromosome banding results. This work was supported by the Spastics Society, the Medical Research Council, and Schering Chemicals Limited.

Requests for reprints should be addressed to: Dr. M. J. Seller, Paediatric Research Unit, Guy's Hospital Medical School, London SE1 9RT.

\section{References}

Alberman, E., and Creasy, M. R. (1974). In Symposium on Chromosome Variations in Human Evolution. In press.

Allan, L. D., Ferguson-Smith, M. A., Donald, I., Sweet, E. M., and Gibson, A. A. M. (1973). Lancet, 2, 522 .

Boué, A., and Boué, J. (1973). Biomedicine, 18, 372.

Brock, D. J. H., and Sutcliffe, R. G. (1972). Lancet, 2, 197.

Gitlin, D., and Boesman, M. (1966). Fournal of Clinical Investigation, 45, 1826 . Gitlin, D., and Boesman, M. (1967). Fournal of Clinical Investigation, 46,
1010.

Seller, M. J., Campbell, S., Coltart, T. M., and Singer, J. D. (1973). Lancet,

Seller, M. J., Singer, J. D., Coltart, T. M., and Campbell, S. (1974). Lancet. 1,428 . 